\title{
Adaptation of Internet Addiction Scale in Azerbaijani Language: A Validity-reliability and Prevalence Study
}

\author{
Melek Kerimova ${ }^{1}$, Selim Gunuc ${ }^{2}$ \\ ${ }^{1}$ School of Humanities and Social Sciences, Khazar University, Baku, Azerbaijan \\ ${ }^{2}$ Department of Computer Education and Instructional Technologies, Yuzuncu Yil University, Turkey \\ Correspondence: Selim Gunuc, Department of Computer Education and Instructional Technologies, Yuzuncu Yil \\ University, Turkey
}

Received: July 30, 2015 Accepted: September 6, 2015 Online Published: September 25, 2015

doi:10.11114/jets.v4i1.1105

URL: http://dx.doi.org/10.11114/jets.v4i1.1105

\begin{abstract}
The purpose of the present paper was to adapt Gunuc and Kayri's (2010) Internet Addiction Scale, with show validity and reliability for many various sampling groups, into the Azerbaijani language. Another objective of the study is to determine the prevalence of Internet addiction among Azerbaijani adolescents and youth, which preemptively requires adaptation of the Internet Addiction Scale into the Azerbaijani language. Samples in the study have been selected separately for both purposes (validity and prevalence). Data were collected from students attending Khazar University in Azerbaijan in 2014-2015, first, in order to conduct Confirmatory Factor Analysis of the scale and second, to determine the prevalence of Internet addiction among youth. Data was obtained from 309 students for the first purpose and from 836 students for the second one. Students in various majors within the research sample were stratified through stratified sampling and students in these majors were randomly selected. The four-factor structure of the scale was tested through CFA. The Cronbach's Alpha $(\alpha)$ internal consistency coefficient of the scale was calculated as $\alpha=.926$. Reliability coefficient of 4 sub-factors, regarding the scale, was found as follows: $\alpha=.844$ for Withdrawal, $\alpha=.821$ for Controlling difficulty, $\alpha=.829$ for Disorder in Functionality and $\alpha=.792$ for Social Isolation. The prevalence of Internet addiction among youth in Azerbaijan was determined. The study found that $51.9 \%$ were not Internet addicts, $40.6 \%$ were moderate Internet addicts, and $7.5 \%$ were Internet addicts. These findings show that the rate of Internet addicts, particularly in the categories of moderate Internet addicts and Internet addicts (48.1\%), is not small enough to ignore.
\end{abstract}

Keywords: Internet addiction, scale, Azerbaijan, adolescent, prevalence, validity

\section{Introduction}

Based on the data presented by Miniwatts Marketing Group (2014), it is stated that the global population is 7.264.623.793 and globally 3.079.339.857 people have access to the Internet. This number represents the $42.4 \%$ of the world population. An increase of $676.3 \%$ is mentioned around the world between 2000 and 2013. Regarding the number of Internet users, China and the USA take the first places whereas Turkey ranks $18^{\text {th }}$. In 2000, Turkey had 2.000.000 Internet users but in 2013 this number went up to 37.748 .969 (http://www.internetworldstats.com/stats.htm).

The Internet in Azerbaijan was first used at the Institute of Information Technologies in National Sciences Academy in 1991. First email service was offered within this institute. The first Internet connection in Azerbaijan in 1994 was provided at Management Branch of Azerbaijan National Sciences Academy, with support from British Petroleum and Turkish Government and Middle East Technical University participation, through Turksat satellite. In 1994, "www.ab.az" website for the first time was created and in 1997, the first government website "www.prezident.az" was built. According to the data presented by Azerbaijan State Statistical Committee (2013), the nationwide rate of households with a computer is $53.2 \%$ and Internet access is $71.6 \%$. Based on the data by "APA-ECONOMICS" (2010), the number of Internet users in Azerbaijan accounts for $44.4 \%$ of the population. This approximately adds up to 3.7 million users. For Azerbaijan, a country with a population of 9.5 million, this number is very crucial (http://www.stat.gov.az/-12.05.2014). Therefore, Internet addiction, as the unwanted face of Internet use, is a concern.

Although the increase in the number of Internet users gives a positive impression based on considerations about possibilities and benefits of Internet use, the status of Internet addiction invokes anxiety and concern. Internet addiction is considered within behavioral addictions such as TV addiction, eating addiction, and shopping addiction. Although, in 
types of substance addiction, concrete symptoms and damages regarding the addicted person's health can be mentioned, it is quite hard to talk about overall damages and, therefore, to define the line between the Internet use and addiction.

It is observed that the concept has been used in various forms within the relevant academic literature. Dr. Ivan Goldberg (1996) was the first to use it in this sense as Internet addiction on international level and it is seen that it was used as Internet dependency. Young defined the concept of Internet addiction, based on pathologic gambling criteria of DSM IV. Internet addiction is considered a new psychiatric disorder within DSM-5 (2013). Researchers following Young and Goldberg who suggest using the concept as pathological Internet use attract attention. Actually, it may be stated that all concepts used share a common ground. It can be said that the most highlighted notion among all of the concepts about extreme and problematic Internet use is related to wasting most of an individual's time on the Internet. For Internet addiction, although time is a criterion, the purpose of using time is important. Individuals who are not Internet-addicted use it for informational, search, and other purposes. However, Internet-addicted individuals are online for long hours and cannot be away from the Internet.

According to international literature, the spread of Internet addiction among adolescents in several countries is as follows: $10.1 \%$ in Turkey (Gunuc \& Kayri, 2010), 5.8\% in Poland (Zboralski et al., 2009), 5.8\% in Italy (Poli \& Agrimi, 2012), 13.5\% in China (Wu et al., 2013), 4.6\% in Romania (Durkee et al., 2012), 17.7\% in Romania (Tsitsika et al., 2014), 5.1\% in Germany (Wölfling \& Muller, 2010), 10.6\% in Germany (Tsitsika et al., 2014), 4.4\% in Europe (Durkee et al., 2012) and $13.9 \%$ in Europe (Tsitsika et al., 2014). It could be stated that these differences from one society to another result from a number of factors such as culture, access to technology, age, parental education, level of income, different measurement tools and different measurement techniques, time of research conducted and selection of research samples (Durkee et al., 2012; Tsitsika et al., 2014).

When distinguishing between an Internet-addicted person and others, many tests, scales, questionnaires, and surveys are used around the world. Today, it is important to accurately define the Internet addiction. In this sense, the need for the scales is on the increase and it can presently be said that the scales are among important economical, practical, and reliable methods of measurement. Although no scales related to Internet addiction is available in Azerbaijan, when relevant international studies are reviewed, it is observed that various measurement tools are used (Young, 1998; Caplan, 2002; Thatcher \& Goolam, 2005; Caplan, 2010; Clark \& Frith, 2005). Some scales, tests, and inventories of Internet addiction are primarily observed when literature about relevant measurement tools is reviewed.

An 8-question "Diagnostic Criteria for Internet Addiction" scale developed by Young in 1996 based on DSM-IV "Substance Addiction" criteria is considered the first among scales internationally utilized in relation to Internet addiction. Later, Young (1998) improved this scale (IAT), adding up to 20 items. This scale has been used with adaptations in countries such as China, Korea, Germany, and Turkey. "The Pathological Internet Use" scale developed by Morahan-Martin and Schumacher (2000) is a Likert-type scale with 13 items.

In addition, various measurement tools such as Caplan's (2002) 5-point Likert-type "Generalized Problematic Internet Use Scale" with 29 items, "Chinese Internet Addiction Inventory" with 31 items developed by Chen and colleagues (2003), "Internet Addiction Scale" with 31 items developed by Nichols and Nicki (2004), "Problematic Internet Use Questionnaire" with 20 items developed by Thatcher and Goolam (2005), "Internet Addiction Scale" with 20 items developed by Kim and colleagues (2006), and "Problematic Internet Use Questionnaire" with 18 items developed by Demetrovics and colleagues (2008) are available. Lastly, "Internet Addiction Scale" with 35 items, developed by Gunuc and Kayri (2010), used in many studies in Turkey, a country culturally close to Azerbaijan, ranks among salient measurement instruments.

As can be observed, prevalence of Internet addiction varies in different countries and the measures used vary as well. In this sense, measures with proven validity and reliability for various samples become more important. Yet, although many studies have been conducted in different countries, it is observed that Azerbaijan lacks empirical research in this field. In this sense, it attracts attention that both no measurement instrument in regards to Internet addiction and no empirical studies on the issue are available in Azerbaijan. Due to the cultural and linguistic similarities between Azerbaijan and Turkish societies, the purpose of this study is to adapt Gunuc and Kayri's (2010) Internet Addiction Scale, with show validity and reliability for many various sampling groups and ages (such as Gunuc, 2015; Gunuc, 2013; Gunuc, 2011; Gunuc \& Dogan, 2013), into the Azerbaijani language. The study also aims to ascertain the prevalence of Internet addiction among Azerbaijani adolescents and youth, which preemptively requires adaptation of the Internet Addiction Scale into the Azerbaijani language.

The present research endeavor, as the first empirical study, qualifies as a pilot study in Azerbaijan to help accurately determine Internet addicts. In other words, the adapted scale is intended as a tool to help define the Internet addicts in Azerbaijan. In addition to clinical observations, the scale is expected to contribute toward defining the prevalence of Internet addicts in larger and different sample groups. 


\section{Method}

\subsection{Sample}

The population for this research project consists of students attending Khazar University. The ages of the participants varied between 18 and 22. Data were collected in classrooms on pencil-and-paper basis in 2014-2015 academic years. Samples in the study have been selected separately for both purposes (validity and prevalence). Data were collected from students attending Azerbaijan Khazar University in 2014-2015, first, for the purpose of Confirmatory Factor Analysis of the scale (validity) and second, in order to determine the prevalence of Internet addiction. Students in various majors within the research sample were stratified through stratified sampling and students in these majors were randomly selected. Data were obtained from 309 students in the first purpose category and from 836 students in the second purpose category.

\subsection{Data Collection Tools}

"Personal Information Form" prepared by researchers and "Internet Addiction Scale" developed by Gunuc and Kayri (2010) as data collection tools were used in the present study. Permission to administer the data collection instruments among students was obtained from Khazar University president's office and relevant explanation was provided to the students about how and where the research results would be used in order for them to provide accurate response.

\subsubsection{Internet Addiction Scale (IAS)}

Because IAS was adapted into the Azerbaijani language, it was tested through its original factor structure CFA, without conducting exploratory factor analysis. IAS was developed in Turkish by Gunuc and Kayri (2010) via a study carried out with 754 adolescents. The average of participants was 15.8. The scale was made up of 35 items. In their study, the Cronbach's Alpha internal consistency coefficient of the five-point Likert-type scale, rated as (1) strongly disagree and (5) strongly agree, was calculated by the researchers as .94. The Cronbach's Alpha (a) reliability coefficients, regarding the four sub-factors of IAS, were calculated as $a=.877$ for the sub-factor of Withdrawal, as $a=.855$ for the sub-factor of Controlling Difficulty, as $a=.827$ for the sub-factor of Disorder in Functionality and as $a=.791$ for the sub-factor of Social Isolation. Higher scores received on the scale indicate Internet addiction.

According to Hambleton and Patsula (1999), just any two bilinguals will not suffice in adapting a scale; they must also be equipped with relevant field expertise. Based on the aforesaid, the original scale was translated into the Azerbaijani language by two bilinguals, of both Azerbaijani and Turkish languages, as experts of Psychological Counselling and Guidance and Cyber-Psychology. No significant differences were noticed between the expert translations. Later, as Hambleton and Patsula (1999) stated, the scale was translated into Turkish by the two experts and their consistency with original item structures was examined. Items on the original scale and the translated items in Turkish were compared on semantic, conceptual, idiomatic, and experiential criteria. Then, the translated scale was administered on 25 students attending various departments and revised based on feedback from the individuals, to complete the process.

\subsection{Data Analysis for CFA}

The goodness-of-fit indices for the model tested through CFA was determined with the help of $\chi^{2}$ (Chi-Square Goodness-of-Fit), GFI (Goodness-of-Fit Index), AGFI (Adjusted Goodness-of-Fit Index), CFI (Comparative Fit Index), NFI (Normed Fit Index), NNFI (Not-Normed Fit Index), RMR (Root Mean Square Residuals), SRMR (Standardized Root Mean Square Residuals) and RMSEA (Root Mean Square Error of Approximation) indices. For the analysis of the data, the package programs of SPSS 18.0 and Lirsel 8.5 (Jöreskog \& Sörbom, 2001) were used for descriptive statistics and confirmatory factor analysis, respectively.

\subsection{Data Analysis for Prevalance}

For prevalence, Two-Step Cluster Analysis was conducted to examine whether the participants were Internet addicts. Cluster analysis is a multivariate statistical technique to categorize individuals or objects in sub-classes or clusters depending on their similarities. The purpose is to gather individuals with similar characteristics in the same group considering a certain characteristic. For this purpose, the similarities or distances between units are used as a criterion (Everitt, 1980; Kaufman \& Rousseeuw, 1990). In this study, the total scores obtained via IAS were used as the criterion for grouping. In this respect, Two-Step Cluster Analysis was conducted; the addicted and non-addicted adolescents were divided in groups; and the profile of the research sample was defined. For the analyses, the significance level was taken as .05 .

\section{Findings}

\subsection{Findings Regarding the Adaptation of Internet Addiction Scale}

\subsubsection{Examining the Assumptions}

For CFA, regarding the data collected from 309 participants found in the sample, z-scores for the univariate outliers and 
Mahalanobis distances for the multivariate outliers were calculated (Huck, 2012; Kline, 2011). 6 students with outliers were excluded from the data set. As the values of both z-scores and Mahalanobis output for are all assumptions of multivariate analyses, were examined (Hutcheson \& Sofroniou, 1999; Kline, 2011; Tabachnick \& Fidell, 2007). The values of skewness $(.252 ; \pm 1)$ and kurtosis $(-.178 ; \pm 1)$ were found to be in acceptable range. In addition, when the histogram, Kolmogorov-Smirnov Normality Test (.200; $>$ >.05), P-P and Q-Q graphics for CFA were examined (Huck, 2012; Pallant, 2007; Kline, 2009), it was seen that the distributions were normal.

\subsubsection{Confirmatory Factor Analysis (CFA)}

The IAS structure was made up of 35 four-factor items. As the data set demonstrated a normal distribution, Maximum Likelihood Method as the parameter estimation method and Covariance Matrix as the data matrix were used in CFA. As can be seen in Table 1, as a result of CFA conducted, the outputs were examined, and primarily the $t$-values, factor loadings and error variances were evaluated.

Table 1. Item Statistics Regarding the CFA Findings

\begin{tabular}{|c|c|c|c|c|c|c|c|c|}
\hline Item & $t$ & $\begin{array}{l}\text { Factor } \\
\text { loading }\end{array}$ & $\begin{array}{l}\text { Error } \\
\text { variance }\end{array}$ & $\mathrm{R}^{2}$ & $\begin{array}{l}\text { Item-Total } \\
\text { cor. (r) }\end{array}$ & scale & $X$ & $\mathrm{Sd}$ \\
\hline \multicolumn{9}{|c|}{ Withdrawal } \\
\hline M1 & $7.91^{*}$ & .46 & .79 & .22 & $.448^{* *}$ & & 2.50 & 1.280 \\
\hline M2 & $9.03^{*}$ & .51 & .74 & .30 & $.484^{* *}$ & & 2.95 & 1.342 \\
\hline M3 & $7.55^{*}$ & .44 & .81 & .23 & $.413^{* *}$ & & 3.57 & 1.220 \\
\hline M4 & $9.52^{*}$ & .54 & .71 & .28 & $.442^{* *}$ & & 2.31 & 1.144 \\
\hline M5 & $11.20^{*}$ & .61 & .62 & .37 & $.525^{* *}$ & & 2.82 & 1.302 \\
\hline M6 & $13.98^{*}$ & .73 & .47 & .53 & $.608^{* *}$ & & 2.57 & 1.234 \\
\hline M7 & $12.87^{*}$ & .68 & .53 & .46 & $.603^{* *}$ & & 2.34 & 1.276 \\
\hline M8 & $9.51^{*}$ & .54 & .71 & .29 & $.444^{* *}$ & & 2.28 & 1.197 \\
\hline M9 & $12.07^{*}$ & .65 & .58 & .42 & $.618^{* *}$ & & 2.25 & 1.236 \\
\hline M10 & $13.67^{*}$ & .72 & .49 & .51 & $.629^{* *}$ & & 2.58 & 1.351 \\
\hline M11 & $10.20^{*}$ & .57 & .68 & .32 & $.508^{* *}$ & & 2.82 & 1.357 \\
\hline \multicolumn{4}{|c|}{ Controlling Difficulty } & & & & & \\
\hline M12 & $10.24^{*}$ & .57 & .68 & .33 & $.567^{* *}$ & & 2.52 & 1.260 \\
\hline M13 & $9.36^{*}$ & .53 & .72 & .28 & $.538^{* *}$ & & 2.62 & 1.402 \\
\hline M14 & $10.52^{*}$ & .58 & .66 & .34 & $.533^{* *}$ & & 2.09 & 1.035 \\
\hline M15 & $9.92^{*}$ & .55 & .69 & .31 & $.555^{* *}$ & & 2.85 & 1.330 \\
\hline M16 & $9.91^{*}$ & .55 & .69 & .30 & $.521^{* *}$ & & 1.98 & 1.079 \\
\hline M17 & $10.98^{*}$ & .60 & .64 & .36 & $.517^{* *}$ & & 2.10 & 1.220 \\
\hline M18 & $11.12^{*}$ & .61 & .63 & .37 & $.536^{* *}$ & & 1.79 & 1.056 \\
\hline M19 & $11.20^{*}$ & .61 & .63 & .38 & $.534^{* *}$ & & 2.09 & 1.145 \\
\hline M20 & $12.40^{*}$ & .66 & .56 & .44 & $.584^{* *}$ & & 1.91 & 1.079 \\
\hline M21 & $11.88^{*}$ & .64 & .59 & .42 & $.590^{* *}$ & & 2.39 & 1.354 \\
\hline \multicolumn{3}{|c|}{ Disorder in Functionality } & $\alpha=.829$ & & & & & \\
\hline M22 & $12.13^{*}$ & .65 & .57 & .41 & $.530^{* *}$ & & 1.95 & 1.168 \\
\hline M23 & $12.18^{*}$ & .66 & .57 & .42 & $.546^{* *}$ & & 1.62 & .871 \\
\hline M24 & $13.25^{*}$ & .70 & .51 & .55 & $.632^{* *}$ & & 2.08 & 1.181 \\
\hline M25 & $12.80^{*}$ & .69 & .53 & .53 & $.637^{* *}$ & & 2.34 & 1.315 \\
\hline M26 & $10.89^{*}$ & .60 & .64 & .35 & $.567^{* *}$ & & 2.31 & 1.235 \\
\hline M27 & $12.89^{*}$ & .69 & .53 & .48 & $.589^{* *}$ & & 2.13 & 1.195 \\
\hline M28 & $12.18^{*}$ & .66 & .57 & .41 & $.531^{* *}$ & & 1.70 & .941 \\
\hline \multicolumn{2}{|c|}{ Social Isolation } & \multicolumn{2}{|c|}{$\alpha=.792$} & & & & & \\
\hline M29 & $12.40^{*}$ & .67 & .55 & .43 & $.454^{* *}$ & & 1.44 & .673 \\
\hline M30 & $12.98^{*}$ & .70 & .51 & .46 & $.443^{* *}$ & & 1.46 & .824 \\
\hline M31 & $10.58^{*}$ & .59 & .65 & .34 & $.320^{* *}$ & & 1.52 & .881 \\
\hline M32 & $11.27^{*}$ & .63 & .61 & .38 & $.461^{* *}$ & & 1.68 & .931 \\
\hline M33 & $12.86^{*}$ & .69 & .52 & .54 & $.603^{* *}$ & & 1.70 & .955 \\
\hline M34 & $9.49^{*}$ & .55 & .70 & .37 & $.590^{* *}$ & & 2.05 & 1.212 \\
\hline M35 & $12.12^{*}$ & .66 & .56 & .42 & $.495^{* *}$ & & 1.86 & 1.147 \\
\hline \multicolumn{2}{|c|}{ Total-Scale Reliability } & \multicolumn{2}{|c|}{$\alpha=.926$} & & & & & \\
\hline
\end{tabular}

As can be seen in Table 1, the $t$-value for each item was higher than +2.58 , and the error variance was lower than .90 . The $t$-value for each indicator in the scale is suggested to be out of the range of $+2.58(p<.01)$ (Kline, 2011; Raykov \& Marcoulides, 2006; Tabachnick \& Fidell, 2007). Accordingly, it was seen that the items had a high level of $t$-value and that the error variance was not much high. The path diagram regarding the model can be seen in Figure 1. 


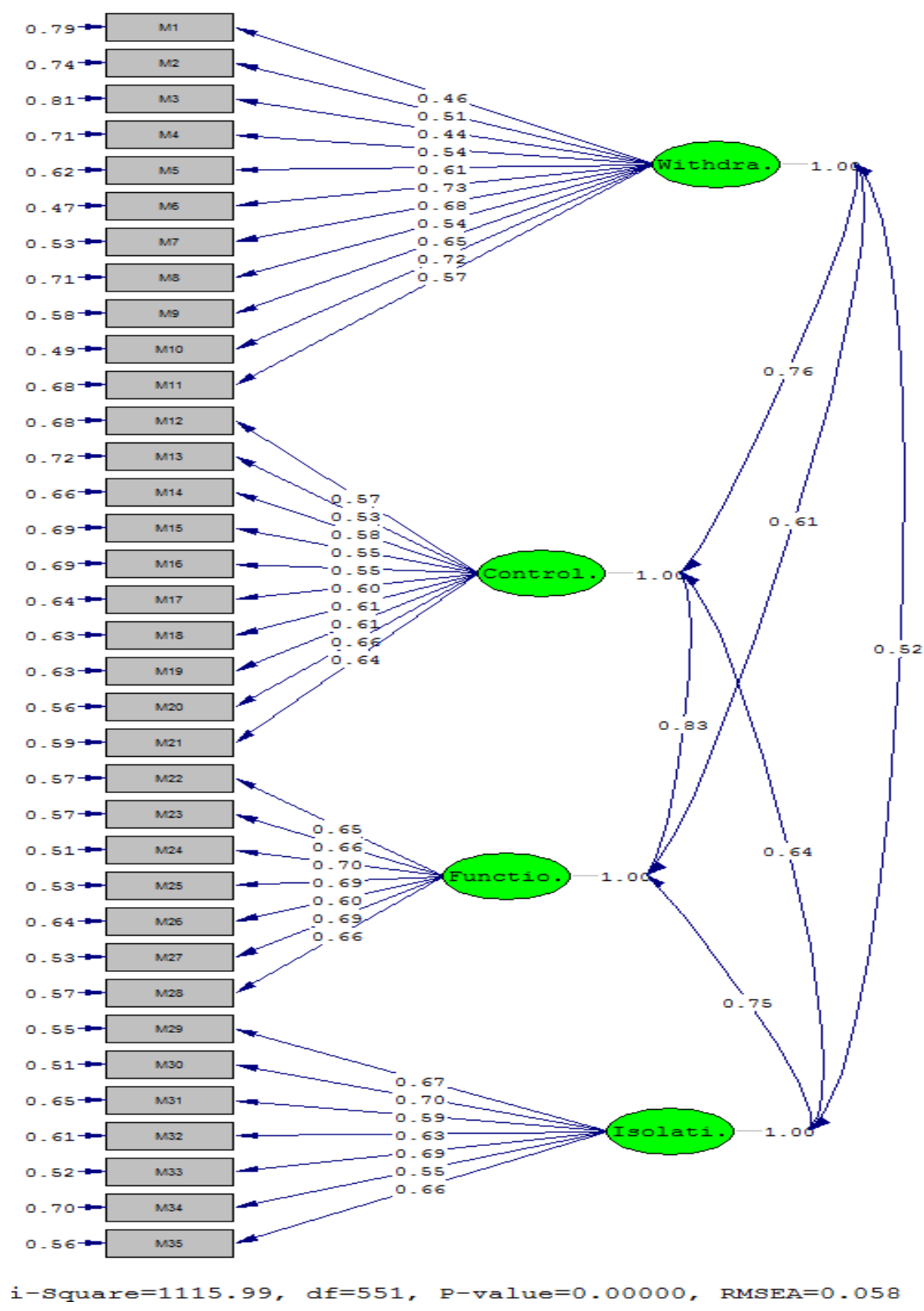

Figure 1.Standardized Path Diagram

When the fit indices of the model were taken into consideration, the $p$ level for the $\chi^{2}$ value was examined. If this value is $p>.05$, then it shows good fit. However, as this value is likely to be significant $(p<.05)$ for large sizes of samples, it is suggested that the ratio of $\chi^{2} / \mathrm{df}$ and other fit indices should be evaluated (Tabachnick \& Fidell, 2007). The Chi-Square value was calculated as $\chi^{2}=1115.99$ and degree of freedom as $\mathrm{df}=551$. If this value is lower than 3 , then, it shows good fit (Kline, 2011; Tabachnick \& Fidell, 2007). In this respect, the ratio of $\chi^{2} / \mathrm{df}(1115.99 / 551)$ was calculated as 2.03. In addition, the other fit indices are presented in Table 2 and evaluated in line with the related literature. 
Table 2.Evaluation of Fit Indices Regarding CFA

\begin{tabular}{llllll}
\hline Index & $\begin{array}{l}\text { Sample } \\
\text { statistic }\end{array}$ & Perfect fit & Good fit & Decision & Rationale \\
\hline$\chi^{2} / \mathrm{df}$ & 2.03 & $\chi^{2} / \mathrm{df} \leq 2$ & $\chi^{2} / \mathrm{df} \leq 3$ & Perfect fit & (Kline, 2011) \\
RMSEA & .058 & RMSEA $\leq .05$ & RMSEA $\leq .08$ & Good fit & Hooper, Coughlan \& Mullen (2008) \\
RMR & .078 & $\mathrm{RMR} \leq .05$ & $\mathrm{RMR} \leq .08$ & Good fit & $\begin{array}{l}\text { Brown (2006) } \\
\text { Hu \& Bentler (1999) }\end{array}$ \\
SRMR & .064 & $\mathrm{SRMR} \leq .05$ & $\mathrm{SRMR} \leq .08$ & Good fit & $\begin{array}{l}\text { Brown (2006) } \\
\text { Hu \& Bentler (1999) }\end{array}$ \\
NFI & .94 & $\mathrm{NFI} \geq .95$ & $\mathrm{NFI} \geq .90$ & Good fit & $\begin{array}{l}\text { Tabachnick \& Fidell (2007) } \\
\text { Thompson (2008) }\end{array}$ \\
NNFI & .97 & $\mathrm{NNFI} \geq .95$ & $\mathrm{NNFI} \geq .90$ & Perfect fit & $\begin{array}{l}\text { Tabachnick \& Fidell (2007) } \\
\text { Thompson (2008) }\end{array}$ \\
CFI & .97 & $\mathrm{CFI} \geq .95$ & $\mathrm{CFI} \geq .90$ & Perfect fit & $\begin{array}{l}\text { Hu \& Bentler (1999) } \\
\text { Tabachnick \& Fidell (2007) }\end{array}$ \\
GFI & .83 & $\mathrm{GFI} \geq .95$ & GFI $\geq .90$ & Poor fit & $\begin{array}{l}\text { Hooper \& colleagues (2008) } \\
\text { Hu \& Bentler (1999) }\end{array}$ \\
\hline$\chi^{2}=1115.99 ; \mathrm{df}=551$ & & &
\end{tabular}

As can be seen in Table 2, it was found out that except for the GFI indices, all the other fit indices had perfect or good fit values. Thus, it could be stated that the model determined to have four factors was confirmed in Azerbaijani language. Table 3 demonstrates the correlations between each factor in the scale and the total-scale as well as those between the factors themselves.

Table 3.Pearson Correlation Coefficients between IAS and the Sub-Factors

\begin{tabular}{llllll}
\hline Factor & Withdrawal & $\begin{array}{l}\text { Controlling } \\
\text { Difficulty }\end{array}$ & $\begin{array}{l}\text { Disorder } \\
\text { Functionality }\end{array}$ & in Social Isolation & Total-Scale \\
\hline Withdrawal & 1 & & & & \\
Controlling Difficulty & $.631^{*}$ & 1 & 1 & 1 \\
Disorder in Functionality & $.512^{*}$ & $.689^{*}$ & $.572^{*}$ & $.721^{*}$ & 1 \\
Social Isolation & $.460^{*}$ & $.532^{*}$ & $.818^{*}$ & \\
Total-Scale & $.843^{*}$ & $.883^{*}$ & & & \\
\hline
\end{tabular}

$$
* p<.001
$$

As can be seen in Table 3, significant correlations were found between each factor and the total-scale $(p<.001)$. In addition, significant correlations were also found between the sub-factors. The fact that there were correlations between the sub-factors proved that separate measurements could be conducted for each factor and that a single measurement could be done using the total scores regarding the total-scale.

\subsubsection{Reliability Analysis Findings as a Result of CFA}

As a result of CFA, the Cronbach's Alpha $(\alpha)$ internal consistency coefficient for the total-scale made up of four factors was calculated as $\alpha=.926$, while it was $\alpha=.844$ for the factor of Withdrawal; $\alpha=.821$ for Controlling Difficulty; $\alpha=.829$ for Disorder in Functionality; $\alpha=.792$ for Social Isolation.

\subsection{Findings regarding the Prevalence of Internet Addiction in Azerbaijan}

\subsubsection{Examining the Assumptions}

Regarding the data collected from 836 participants found in the sample. 4 students with outliers were excluded from the data set. As the values of both z-scores and Mahalanobis output for the remaining 832 students were in acceptable range, no other outliers were observed in the data set. The values of skewness $(.391 ; \pm 1)$ and kurtosis $(.037 ; \pm 1)$ were found to be in acceptable range. In addition, when the histogram, Kolmogorov-Smirnov Normality Test (.055; $p>.05)$, P-P and Q-Q graphics were examined, it was seen that the distributions were normal.

\subsubsection{Reliability Analysis Findings as a Result of Prevalence}

As a result of CFA, the Cronbach's Alpha $(\alpha)$ internal consistency coefficient for the total-scale made up of four factors was calculated as $\alpha=.927$, while it was $\alpha=.836$ for the factor of Withdrawal; $\alpha=.821$ for Controlling Difficulty; $\alpha=.839$ for Disorder in Functionality; $\alpha=.779$ for Social Isolation. 
Table 4. Descriptive statistics regarding total-scale and sub-scale

\begin{tabular}{lllll}
\hline Factor & $\mathrm{N}$ & Mean & Mean/Items & Sd. \\
\hline Withdrawal & 832 & 28,962 & 2,632 & 8,282 \\
Controlling Difficulty & 832 & 22,242 & 2,224 & 7,384 \\
Disorder in Functionality & 832 & 14,287 & 2,041 & 5,661 \\
Social Isolation & 832 & 12,208 & 1,744 & 4,753 \\
Total-scale & 832 & 77,698 & 2,220 & 21,656 \\
\hline
\end{tabular}

Table 5. Grouping of the IAS Total Scores with Two-Step Cluster Analysis

\begin{tabular}{lllll}
\hline IAS & & & & \\
\hline Group & $\mathrm{N}$ & $\%$ & Mean & Sd \\
1 (non-addicted group) & 432 & 51.9 & 61,294 & 11,604 \\
2 (addiction risk group) & 338 & 40.6 & 90,249 & 8,880 \\
3 (addicted group) & 62 & 7.5 & 123,581 & 9,134 \\
Total & 832 & 100,0 & 77,698 & 21,656 \\
\hline
\end{tabular}

When Table 5 is examined, it is seen that the number of Internet addicts was $62(7.5 \%)$ and that the number of moderate Internet addicts (addiction risk group) was 338 (40.6\%). The first group represented the non-addicted participants, and the second group represented the participants with the risk of addiction. Regarding this grouping, it could be stated that the first group did not have any symptoms of addiction at all; that the second group with the risk of addiction showed some of the symptoms of addiction, and that the third group, the addicted group, showed most of the symptoms of addiction.

In addition, the first group represented the non-addicted participants with Internet addictions, and the second group represented the participants with the risk of addiction. Regarding this grouping, it could be stated that the first group did not have any symptoms of addiction at all; that the second group with the risk of addiction showed some of the symptoms of addiction (some of items were 4 or 5 point), and that the third group, the addicted group, showed most (or all) of the symptoms of addiction.

\section{Conclusion and Discussion}

In this study, "Internet Addiction Scale" developed by Gunuc \& Kayri (2010), was adapted into the Azerbaijani language. In this sense, instead of developing a new measure, it was considered convenient based on cultural and language similarities to use a measure with validity and reliability proven in many studies. It attracts attention that no Internet addiction scale was developed and the prevalence of Internet addiction was not examined in Azerbaijan previously. As this study is the first in this specific area and would be a pioneer for future research, it is expected to significantly contribute, particularly, to the literature in Azerbaijan.

This research was conducted in two steps. In the first step, the validity and reliability studies for the scale were conducted. Upon having the factor structure of scale confirmed, the prevalence of Internet addiction was determined in a larger sample. In both steps, students were randomly selected from different majors, through stratified sampling. Data were obtained from 309 students in the sample of the first administration and 836 students in the sample of second administration.

The four-factor structure of the scale was tested through CFA. The Cronbach's Alpha $(\alpha)$ internal consistency coefficient of the scale was calculated as $\alpha=.926$. Reliability coefficient of 4 sub-factors, regarding the scale, was found as follows: $\alpha=.844$ for Withdrawal, $\alpha=.821$ for Controlling Difficulty, $\alpha=.829$ for Disorder in Functionality and $\alpha=.792$ for Social Isolation. Both item values and CFA indices were obtained on good levels. Both factor structure and item number of the original scale were preserved and confirmed. Based on these results, scale structure was shown to be robust enough to use in Azerbaijan.

Each item in the scale is positive and the total score obtained in the scale refers to the Internet addiction. In this sense, when the scale is used, comparison or relational analyses can be conducted between the total score obtained in the scale and the demographic variables. Besides, upon two-step cluster analysis over total scores, Internet addicts and non-addicts can be assigned into groups. Re-comparative analyses can be conducted in these newly drawn groups. In addition, Internet addicted persons can be scored through a quite simpler but scientifically weak method. In this sense, those over $105(3 * 35)$, as the total score obtained in the scale, can be considered Internet addicts. These can be categorized into three groups such as non-Internet addicts, moderate Internet addicts, and Internet addicts. Then, those between $105(3 * 35)$ and $140(4 * 35)$ may be considered moderate Internet addicts as those over 140 can be considered Internet addicts. In this context, moderate Internet addiction means that individuals have some symptoms of Internet 
addiction and Internet addicts, on the other hand, have most or all symptoms of Internet addiction. It must be taken into consideration that all scoring methods, mentioned and not mentioned, can be used based on researchers' experiences, however, two-step cluster as a scientific method is recommended for stratifying individuals by the researchers in this study. In addition, comparing total scores to other variables and directly including them in relational analyses are also recommended as a scientific method.

In the second step, prevalence of Internet addiction among adolescents and youth in Azerbaijan was determined. It was found in the research that $51.9 \%$ were not Internet addicts, $40.6 \%$ were moderate Internet addicts, and $7.5 \%$ were Internet addicts. These findings show that the rate of Internet addicts, particularly with moderate Internet addicts and Internet addicts (48.1\%), is not small enough to ignore. A comparison with other rates or different samples is not possible as there are no studies available in the national literature on the prevalence of Internet addiction in Azerbaijan. However, a review of findings in this context within international literature reveals similar rates in many countries. Yet, it is remarkable that moderate Internet addicts account for $40.6 \%$ in this research, compared to $26.4 \%$ in Turkey (Gunuc \& Kayri, 2010) and 5.01\% in Italy (Poli \& Agrimi, 2012). Besides, it could be stated that these differences from one society to another stem from a number of factors such as culture, access to technology, age, parental education, level of income, different measurement tools and different measurement techniques, time of research conducted and selection of research samples (Durkee et al., 2012; Tsitsika et al., 2014).

Some precautions and treatments for addicts must be planned based on findings of future researches similar to this study in Azerbaijan. In order for moderate Internet addicts, in other words, users at risk, not to turn into addicts in time, families and educators must take on some responsibilities. However, prior to implementing any precautions or treatments, possible motives for Internet addiction must be defined particularly through case study method. Although international literature presents some findings on these factors, they may have different effect levels based on cultural differences. In this context, the Internet addiction scale adapted within this study is suggested for use as a diagnosis tool in clinical settings. In addition, investigating various demographic variables in different sample groups in Azerbaijan and evaluating the results following this process will present more robust data.

An important limitation within this study is that data were collected at one university. Even though, the number of samples is enough, a more comprehensive study to be conducted in Azerbaijan may more clearly reveal the prevalence of Internet addiction. The focus of this research has been about contributing a measurement tool needed in Azerbaijan in the national literature. Also, lack of prevalence of empirical studies in Azerbaijan prevented data collection from universities. With the introduction of measurement tool developed within this study, an increase in future empirical research is expected.

\section{References}

Brown, T. A. (2006). Confirmatory factor analysis for applied research. New York, NY: Guilford Publications, Inc.

Byrne, B. (2010). Structural equation modeling with AMOS: Basic concepts, applications and programming. New York, NY: Taylor and Francis Group.

Caplan, S. E. (2002). Problematic internet use and psychosocial well-being: development of a theory-based cognitive behavioral measurement instrument. Computer Human Behavior, 18, 553-575. http://dx.doi.org/10.1016/S0747-5632(02)00004-3

Caplan, S. E. (2010). Theory and measurement of generalized problematic internet use: a two-step approach. Computer Human Behavior, 26, 1089-1097. http://dx.doi.org/10.1016/j.chb.2010.03.012

Chen, S., Weng, L., \& Su, Y., et al. (2003).Development of a Chinese Internet addiction scale and its psychometric study. Chinese Journal of Psychology, 45, 279-294.

Clark, D. J., \& Frith, K. H. (2005). The development and initial testing of the Internet Consequences Scales (ICONS), Computer Information Nurs, 23, 285-291. http://dx.doi.org/10.1097/00024665-200509000-00013

Demetrovics, Z., Szeredi, B., \& Rózsa, S. (2008). The three-factor model of internet addiction: The development of the problematic internet use questionnaire. Behavior Research Methods, 40(2), 563-574. http://dx.doi.org/10.3758/BRM.40.2.563

Durkee, T., Kaess, M., \& Carli, V., et al. (2012). Prevalence of pathological internet use among adolescents in Europe: Demographic and social factors. Addiction, 107, 2210-2222. http://dx.doi.org/10.1111/j.1360-0443.2012.03946.x

Everitt, B. S. (1980). Cluster Analysis (2 ${ }^{\text {nd }}$ ed.). London: Heinemann Educational Books.

Gunuc, S. (2015).Relationships and Associations between Video Game and Internet Addictions: Is Tolerance a Symptom Seen in All Conditions? Computer in Human Behavior, 49, 517-525. http://dx.doi.org/10.1016/j.chb.2015.03.063 
Gunuc, S. (2013). Cart and Chaid analyses of some variables that predict internet addiction. Turkish Journal of Psychology, 28(71), 88-101.

Gunuc, S., \& Dogan, A. (2013).The Relationships between Turkish Adolescents' Internet Addiction, Their Perceived Social Support and Family Activities. Computers in Human Behavior, 29(6), 2197-2207. http://dx.doi.org/10.1016/j.chb.2013.04.011

Gunuc, S. (2011). Examination of Internet Addiction among Computer Department Staff in Terms of Duration and Purpose of Its Use. International Journal of Cyber Society and Education, 4(1), 39-46.

Gunuc, S., \& Kayri, M. (2010). The profile of Internet Dependency in Turkey and Development of Internet Addiction Scale: Study of Validity \& Reliability. Hacettepe University Journal of Education, 39, 220-232.

Hambleton, R. K., \& Patsula, L. (1999). Increasing the validity of adapted tests: myths to be avoided a guidelines for improving test adaptation practices. Journal of Applied Testing Technology, August 1999 Issue. http://data.memberclicks.com/site/atpu/volume\%201\%20issue\%201Increasing\%20validity.pdf

Hooper, D., Coughlan, J., \& Mullen, M. (2008). Structural equation modelling: guidelines for determining model fit. Articles, 2.http://dx.doi.org/10.1007/978-3-319-19027-3

Hu, L. T., \& Bentler, P. M. (1999). Cutoff Criteria for Fit Indexes in Covariance Structure Analysis: Conventional Criteria Versus New Alternatives. Structural Equation Modeling, 6(1), 1-55. http://dx.doi.org/10.1080/10705519909540118

Huck, S. (2012).Reading statistics and research (6 $6^{\text {th }}$ ed.). Boston: Pearson.

Hutcheson, G. D., \& Sofroniou, N. (1999). The multivariate social scientist: An introduction to generalized linear models. Sage Publications.

Jöreskog, K., \& Sörbom, D. (2001). Lisrel 8: User's reference guide. Chicago, USA: Scientific Software International Inc.

Kaufman, L., \& Rousseeuw, P. J. (1990). Finding groups in data: An introduction to cluster analysis. New York: John Wiley and Sons. http://dx.doi.org/10.1002/9780470316801

Kim, K., Ryu, E., \& Chon, M. Y., et al. (2006). Internet addiction in Korean adolescents and its relation to depression and suicidal ideation: a questionnaire survey. International Nurs Stud, 43, 185-192. http://dx.doi.org/10.1016/j.jinurstu.2005.02.005

Kline, R. B. (2011). Principles and practice of structural equation modeling (3th ed.) New York: The Guilford Press.

Morahan-Martin, J., \& Schumacher, P. (2000).Incidence and correlates of pathological internet use among college students. Computers in Human Behavior, 16, 13-29. http://dx.doi.org/10.1016/S0747-5632(99)00049-7

Nichols, L. A., \& Nicki, R. (2004). Development of a Psychometrically Sound Internet Addiction Scale: A Preliminary Step. Psychology of Addictive Behaviors, 18(4), 381-384.http://dx.doi.org/10.1037/0893-164X.18.4.381

Pallant, J. (2007). SPSS survival manual: A step by step guide to data analysis using SPSS for Windows. Maidenhead: Open University Press.

Poli, R., \& Agrimi, E. (2012). Internet addiction disorder: Prevalence in an Italian student population. Nordic Journal of Psychiatry, 66(1), 55-59. http://dx.doi.org/10.3109/08039488.2011.605169

Raykov, T., \& Marcoulides, G. A. (2006). A first course in structural equation modeling (2nd ed. Lawrence Erlbaum Associates, Inc. Publishers.

Tabachnick, G. G., \& Fidell, L. S. (2007).Experimental designs using ANOVA. Belmont, CA: Duxbury, 35, 793-809.

Thatcher, A., \& Goolam, S. (2005). Development and psychometric properties of the Problematic Internet Use Questionnaire. South African Journal Psychology, 35,793-809. http://dx.doi.org/10.1177/008124630503500410

Tsitsika, A., Janikian, M., \& Schoenmakers, T. M., et al. (2014). Internet Addictive Behavior in Adolescence: A Cross-Sectional Study in Seven European Countries. Cyberpsychology, Behavior, and Social Networking, 17(8), 528-535. http://dx.doi.org/10.1089/cyber.2013.0382

Wölfling, K., \& Muller K. W. (2010).Pathological gambling and computer game-addiction. Current state of research regarding two subtypes of behavioral addiction. Bundesgesundheitsblatt, Gesundheitsforschung, Gesundheitsschutz, 53(4), 306-312. http://dx.doi.org/10.1007/s00103-010-1038-7

Wu, X., Chen, X., Han, J., Meng, H., \& Luo, J., et al. (2013). Prevalence and Factors of Addictive Internet Use among Adolescents in Wuhan, China: Interactions of Parental Relationship with Age and Hyperactivity-Impulsivity. PLoS 
ONE 8(4): e61782. http://dx.doi.org/10.1371/journal.pone.0061782

Young, K. S. (1998). Internet Addiction: The Emergence of a New Clinical Disorder. CyberPsychology and Behavior, 1(3), 237-244. http://dx.doi.org/10.1089/cpb.1998.1.237

Zboralski, K., Orzechowska, A., \& Talarowska, M., et al. (2009).The prevalence of computer and Internet addiction among pupils. PostepyHigieny I Medycyny Do wiadczalnej (Online), 63, 8-12.

Statistics Azerbaijan. (2010). Retrieved from http://www.stat.gov.az/menu/6/statistical_yearbooks/

Internet World Stats. (2015). Retrieved from http://www.internetworldstats.com/stats.htm

Appendix. Internet Addiction Scale for Azerbaijani Form

\begin{tabular}{|c|c|c|c|c|c|}
\hline 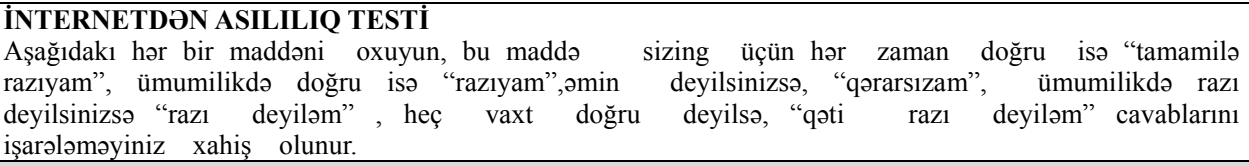 & 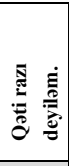 & 胥 & 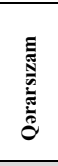 & 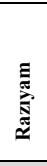 & 莃 \\
\hline \multicolumn{6}{|l|}{ Oksiklik } \\
\hline \multirow{2}{*}{\multicolumn{6}{|c|}{$\begin{array}{lccccccccc}\text { 1. İnternetdən } & \text { istifadə } & \text { etmədiyim } & \text { zaman } & \text { özümü } & \text { gərgin, narahat hiss edirəm. } & & \\
\begin{array}{l}\text { 2. İnternetdən } \\
\text { oluram. }\end{array} & \text { istifadə } & \text { etmək } & \text { istəyib } & \text { də } & \text { edə } & \text { bilmədikdə çox hirsli } & \text { və } & \text { qəzəbli } \\
\end{array}$}} \\
\hline & & & & & \\
\hline 3. İnternet əlaqəsi $\quad$ kəsiləndə $\quad$ ya da yavaşlayanda $\quad$ hirslənirəm / qəzəblənirəm. & & & & & \\
\hline \multicolumn{6}{|l|}{$\begin{array}{l}\text { 4. İnternetdən istifadə etdiyim zaman heç vaxt olmadığım qədər } \\
\text { edirəm. }\end{array}$} \\
\hline \multicolumn{6}{|l|}{$\begin{array}{lllllll}\text { 5. Özümü } & \text { narahat } & \text { və } & \text { sıxıntılı } & \text { hissetdiyim } & \text { zamanlarda } & \text { internetdən istifadə etmək məni } \\
\text { sakitləşdirir. } & & & & & \end{array}$} \\
\hline \multicolumn{6}{|l|}{ 6. Kimsə $\quad$ məni $\quad$ internetdən $\quad$ ayırırsa $\quad$ hirslənirəm. } \\
\hline \multicolumn{6}{|l|}{ 7. Problemlərimdən qaçmaq üçün internetdən istifadə edirəm. } \\
\hline \multicolumn{6}{|l|}{ 8. İnternetə $\quad$ planlaşdırdığım $\quad$ vaxt $\quad$ girmədiyimdə $\quad$ hirslənirəm. } \\
\hline 9. Otrafımda insanlar olduğu vaxt tək qalıb internetə girmək & & & & & \\
\hline \multicolumn{6}{|l|}{ 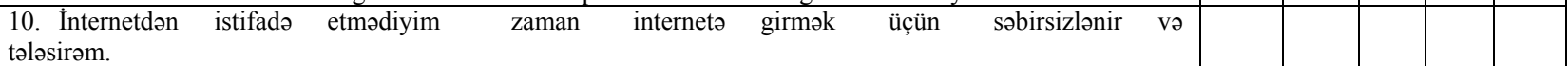 } \\
\hline \multicolumn{6}{|l|}{ 11. Getdiyim məkanlarda internet əlaqəsi $\quad$ axtarıram. } \\
\hline \multicolumn{6}{|l|}{ Nəzarət $\quad$ etmədə $\quad$ çtinlik } \\
\hline \multicolumn{6}{|l|}{ 12. İnternet istifadəsinə məhdudiyyət qoymaqda və nəzarət etməkdə çətinlik çəkirəm. } \\
\hline \multicolumn{6}{|l|}{ 13.Səhər $\quad$ oyananda ilk ağlıma gələn $\quad$ fikir internetə $\quad$ girməkdir. } \\
\hline \multicolumn{6}{|l|}{ 14. İnternetdə hər səfərində } \\
\hline \multicolumn{6}{|l|}{ 15. İnternetdə $\quad$ planlaşdırdığımdan $\quad$ daha $\quad$ uzun müddət $\quad$ qalıram. } \\
\hline \multicolumn{6}{|l|}{ 16. İnternetdən istifadə etmədiyim zamanlarda belə internet fikirləşirəm. } \\
\hline \multicolumn{6}{|l|}{ 17. İnternetdə ikən aclığımı, susuzluğumu hiss etmirəm ya da fərqinə varmıram. } \\
\hline \multicolumn{6}{|l|}{ 18. İnternetdə daha uzun vaxt keçirmək üęün başqa planlarımı ləğvedirəm. } \\
\hline \multicolumn{6}{|l|}{ 19. İstədiyim zaman internetdən ayrila bilmirəm. } \\
\hline \multirow{2}{*}{\multicolumn{6}{|c|}{\begin{tabular}{lllll} 
20. Ailəm məni & \multicolumn{2}{c}{ çağırsa da internetdən } & ayrıla & bilmirəm. \\
21. İnternetdən & istifadə etmək ücün & yuxumu & ertələyirəm.
\end{tabular}}} \\
\hline & & & & & \\
\hline \multicolumn{6}{|l|}{ Funksional pozulma } \\
\hline \multicolumn{6}{|l|}{ 22. İnternetdən istifadə etdiyim üçün ailəmlə } \\
\hline \multicolumn{6}{|l|}{ 23. Dostlar $\quad$ məni $\quad$ çağırsa da internetdən $\quad$ ayrıla $\quad$ bilmirəm. } \\
\hline \multicolumn{6}{|l|}{ 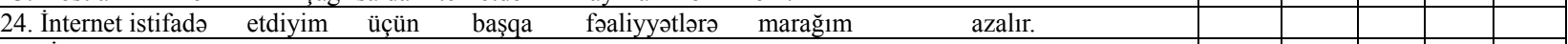 } \\
\hline \multicolumn{6}{|l|}{$\begin{array}{lllllll}\begin{array}{l}\text { 25. Internet istifadə } \\
\text { bilmirəm ya da etmək }\end{array} & \begin{array}{c}\text { etdiyimə } \\
\text { istəmirəm. }\end{array} & \text { görə } & \text { ev/işs/məktəb } & \text { məsuliyyətlərimi } & \text { yerinə } & \text { yetirə } \\
\end{array}$} \\
\hline \multicolumn{6}{|l|}{ 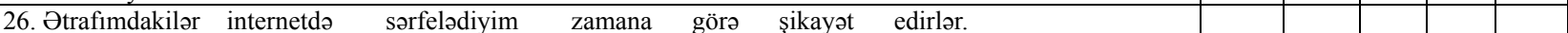 } \\
\hline 27. İnternetdən istifadə etdiyim ü̈çün ailəmilə daha az zaman $\quad$ keçirirəm. & & & & & \\
\hline 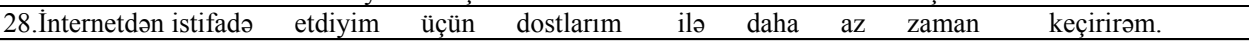 & & & & & \\
\hline Sosial tocridolma & & & & & \\
\hline 29. İnternetdən istifadə etdiyim üçün yoldaşlarım ilə problemlər yaşayıram. & & & & & \\
\hline 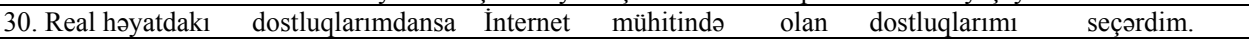 & & & & & \\
\hline $\begin{array}{l}\begin{array}{l}\text { 31. Real həyatdakı dostlarımla } \\
\text { verərəm. }\end{array} \\
\end{array}$ & & & & & \\
\hline 32. Dostlarımı internet üzərindən & & & & & \\
\hline 33. İnternet mənim ən $\quad$ yaxşı & & & & & \\
\hline mənasız və boş gəlir. & & & & & \\
\hline $\begin{array}{llll}\text { etdiyim } & \text { üçün } & \text { üz üzə } & \text { ünsiyyət } \\
\end{array}$ & & & & & \\
\hline
\end{tabular}

\section{$(c)$ EY}

This work is licensed under a Creative Commons Attribution 3.0 License. 